\title{
Tadeusz Lewowicki, Ewa Ogrodzka-Mazur, Aleksandra Minczanowska i Gabriela Piechaczek-Ogierman: Sfery życia duchowego dzieci i mtodzieży - studium z pogranicza polsko-czeskiego. Tom 1. Przemiany wartości i aspiracji życiowych. Toruń 2016, Wydawnictwo Adam Marszałek, ss. 273
}

„Przemiany wartości i aspiracji życiowych” to studium panelowe, którego przedmiotem zainteresowania są wartości i aspiracje. Autorzy, czyli Tadeusz Lewowicki, Ewa Ogrodzka-Mazur, Gabriela Piechaczek-Ogierman i Aleksandra Minczanowska, bezpośrednim przedmiotem swych badawczych eksploracji uczynili wartości i aspiracje deklarowane przez dzieci i młodzież. Miejscem badań jest pogranicze polsko-czeskie.

Muszę jednocześnie dopowiedzieć, że owo pogranicze nie stanowi wyłącznie egzemplifikacji empirycznej, chociaż tak można je spostrzegać - przykładowo - z perspektywy teorii wychowania. Pogranicze jest w tej książce wartością samą w sobie, co lokuje badania w przestrzeni namysłu pedagogiki międzykulturowej. Druga ważna kwestia: Autorzy przedmiotem swej refleksji uczynili wyniki badań z lat 1990-1991 i 2014-215. Nie są to jednak badania podłużne, ale obejmują one dwie populacje dzieci i młodzieży, które łączy fakt, że zamieszkują to samo pogranicze polsko-czeskie, a więc ten sam obszar geograficzny, historyczny, społeczny i polityczny. Pierwsza grupa badanych (z lat 1990-1991) to pokolenie, którego osobowość i tożsamość zostały ukształtowane w rzeczywistości socjalistycznej, czyli przedtransformacyjnej, chociaż badania zrealizowano po 1989 roku. Druga (z lat 2014-2015) to pokolenie potransformacyjne, które przyszło na świat i było/ jest kształtowane w nowej rzeczywistości społeczno-politycznej i gospodarczej. Wykorzystanie wyników badań dwóch sondaży pomogło Autorom uchwycić charakter i dynamikę zmian w obszarze deklarowanych przez młodych wartości, aspiracji, planów życiowych, samooceny, wzorów osobowości i cech cenionych u innych ludzi. Na ważność związków pomiędzy wymienionymi obszarami wskazuje już we „Wstępie” Tadeusz Lewowicki (Lewowicki, 2016a, s. 10), a wykorzystana przez wszystkich Autorów strategia porównań pozwoliła rozpoznać pewne prawidłowości dynamiki zmian (Ogrodzka- 
-Mazur, 2016b, s. 45 i nn.), które trzeba uznać za znaczące tak dla edukacji, jak i pedagogiki, ale także dla wszystkich nauk społecznych.

Takie podejście metodologiczne otworzyło przed Badaczami możliwość zrekonstruowania obrazu kondycji człowieka pogranicza. Było to możliwe za sprawą przyjęcia wizji człowieka jako tego, który nieustannie musi układać się z otaczającym światem. To układanie (się) ze światem można badać nie tylko przez badanie zachowań tożsamościowych, jak to proponuje Tadeusz Lewowicki w swej Teorii Zachowań Tożsamościowych, ale także przez badanie sfery wartości, co proponuje Ewa Ogrodzka-Mazur (2016b, s. 95). Układanie się ze światem pociąga za sobą konieczność (de)konstrukcji sfery psychologicznej, kulturowej i duchowej człowieka (Ogrodzka-Mazur, 2016b, ss. 95-96). Tak więc autorzy książki dzięki badaniom i ich krytycznemu opracowaniu przekonują czytelnika, że transformacja ustrojowa, a także wymuszana przez nią transformacja wartości pociągają za sobą również dekonstrukcję sfery psychologiczno-duchowej człowieka (por. Ogrodzka-Mazur, 2016b, ss. 95-96). Jednakże ani transformacja wartości, ani dekonstrukcja sfery psychologiczno-duchowej nie usuwają podmiotu, lecz organizują go na nowo i otwierają przed nim nowe możliwości bycia w świecie.

Badania z lat 1990-1991 i 2014-2015 to dwie diagnozy społeczne. Druga objęła swoim zasięgiem deklaracje dzieci i młodzieży, które - jak pisałam - urodziły się, i których osobowość oraz tożsamość były/są kształtowane w okresie potransformacyjnym. Jednakże skutki transformacji społeczno-politycznej i ekonomicznej odcisnęły/odciskają swoje piętno na tym, jakie wartości i aspiracje są dla młodych (przynajmniej deklaratywnie) ważne. Można zatem przyjąć, że będą one determinować biografie edukacyjne i zawodowe pokoleń potransformacyjnych, niezależne od tego, czy wychowują się one na pograniczu polsko-czeskim, czy wychowują się w Polsce, czy też w Republice Czeskiej. Wspólne bowiem obywatelom czeskim i obywatelom polskim jest doświadczenie pokojowej zmiany ustroju. Podjęte przez Autorów w tym obszarze studia dowodzą, że badania pedagogiczne i edukacyjne uwzględniać powinny fakt transformacji ustrojowej, zwłaszcza jeśli dotyczą one wartości i aspiracji (nawet jeśli są to wartości i aspiracje deklarowane przez najmłodsze pokolenie). Przyjęte stanowisko metodologiczne jest w książce gruntowane tezami m.in. Ewy Ogrodzkiej-Mazur i Gabrieli Piechaczek-Ogierman.

Tezę Ewy Ogrodzka-Mazur, że każda transformacja ustrojowa swoiście wymusza transformację aksjologiczną (Ogrodzka-Mazur, 2016b, s. 35 i nn.), rozwija Gabriela Piechaczek-Ogierman, pisząc, że każda taka transformacja wpływa na kształt aspiracji i planów życiowym dzieci i młodzieży, a także 
na ich wybory edukacyjne. W przypadku badanej populacji (w latach 2014-2015) ma to związek również z deklarowaną chęcią zdobycia wyższego wykształcenia (Piechaczek-Ogierman, 2016, s. 170). Innymi słowy, transformacja ustrojowa jest nie tylko punktem zwrotnym życia wspólnotowego, ale zmienia trajektorię każdej człowieczej biografii (Piechaczek-Ogierman, 2016, s. 171).

Na uwagę zasługuje wypracowana przez Autorów struktura książki, która wynika z pogrupowania treści według - jak się wydaje - poznawczych i naukowych preferencji Autorów. Ewa Ogrodzka-Mazur w rozdziale „Dzieci i młodzież z Pogranicza - uczniowie ze szkół podstawowych i gimnazjalnych w roku 2015 - charakterystyka środowiska i badanych grup" (2016a) opis badanych grup osadza we właściwych im kontekstach demograficznym, prawnym, społecznym i politycznym. Dla całości pracy ważna jest uwaga o zaniku na pograniczu jednoznacznej identyfikacji polskiej i ujawnianiu się samoidentyfikacji śląskiej bądź morawskiej, co Badaczka wiąże z procesem asymilacji (Ogrodzka-Mazur, 2016a, s. 22, por. także Ogrodzka-Mazur, 2016b, s. 50). Drugi z kolei rozdział, także autorstwa Ewy Ogrodzkiej-Mazur, pt. „Wartości cenione przez uczniów z pogranicza polsko-czeskiego” (2016b), budowany jest na twierdzeniu, że „nie można zrozumieć człowieka” bez rozpoznania jego systemu wartości, bowiem te decydują o egzystencji człowieka. Teza ujawnia antropologiczno-pedagogiczny sens badań nad wartościami. Ich rozpoznanie i zrozumienie pozwala - jak już wspomniałam wcześniej rozpoznać i zrozumieć kondycję człowieka, która zawsze jest kondycją człowieka określonego czasu i miejsca (Ogrodzka-Mazur, 2016b, s. 27).

Wątek wartości jest rozwijany w dwóch kierunkach. Pierwszy - podjęty przez Gabrielę Piechaczek-Ogierman (2016) - związany jest z ekonomizacją życia i przesunięciem aktywności człowieka w kierunku działalności silnie determinowanej przez rynek pracy. Drugi - podjęty przez Aleksandrę Minczanowską (2016) - osadzony jest w optyce kultury popularnej, właściwie w jej skrajnej postaci, czyli w konsumpcjonizmie. W takim ujęciu człowiek rozumiany jest jako konsument i ta dystynkcja profiluje jego system wartości i aspiracji.

W rozdziale „Aspiracje i plany życiowe dzieci i młodzieży” (2016) Gabriela Piechaczek-Ogierman osadza wyniki badań w optyce m.in. gospodarki kapitałowej i - wspomnianym już - rynku pracy. Badaczka w analizowanym materiale empirycznym uchwyciła dwie prawidłowości: pierwsza odnosi się do faktu, że młodzież świadomość trudności, jakie może napotkać człowiek na rynku pracy; druga to uświadomiona przez młodzież potrzeba(?)/ ko- 
nieczność(?) posiadania satysfakcjonującego życia. Obie te kwestie mogą w takim samym stopniu mobilizować, jak i zniechęcać młodych do „osiągania celów życiowych" (Piechaczek-Ogierman, 2016, s. 100 i nn.). Edukacyjnie i pedagogicznie ważny jest rozpoznawany i opisany przez Badaczkę związek między transformacją społeczno-polityczną i ekonomiczną a deklarowanymi aspiracjami i planami życiowymi, a także deklarowaną potrzebą posiadania wyższego wykształcenia (Piechaczek-Ogierman, 2016, ss. 170-171). Autorka obserwuje wzrost aspiracji edukacyjnych w deklaracjach pozyskanych w badaniach z lat 2014-2015 (Piechaczek-Ogierman, 2016, ss. 172-173).

Aleksandra Minczanowska w rozdziale „Samoocena, wzory osobowe i cenione przez uczniów z Pogranicza cechy u innych ludzi" (2016) - jak napisałam - szkicuje obraz społeczeństwa konsumpcyjnego. Niebezpieczeństwo konsumpcjonizmu wynika z faktu, że jest on skupiony na „tu i teraz” człowieka, przez co odrywa go od historyczności jego wspólnoty. Tym samym konstruuje teraźniejszość, której kultura ma być rozrywkowa, indywidualna, subiektywna i zliberalizowana, przy równoczesnym ograniczeniu wpływów przeszłości (Minczanowska, 2016, s, 175). Antropologia konsumpcjonizmu skupia się na wizji człowieka życzliwego, uśmiechniętego i wesołego (Minczanowska, 2016, s. 214), naznaczonego natychmiastowością (Minczanowska, 2016, s. 176), chcącego „wyzwolić się” z przeszłości, tj. z dziedzictwa kulturowego wspólnoty. Kryje się w tym jednak pułapka, gdyż wyzwolenie z kultury wspólnoty powoduje, że człowiek wpada w pułapkę kultury popularnej (Minczanowska, 2016, s. 214). To swoiste uwikłanie człowieka w konsumpcjonizm wytwarza nowy typ więzi, które Badaczka rozpoznaje jako powiązania wsparte na kalkulacji i wyrachowaniu (Minczanowska, 2016, s. 175). Jest tu jednak pewien „edukacyjny optymizm”, wzrastają bowiem oczekiwania wobec nauczycieli, którzy powinni pomóc młodym (z)rozumieć otaczający ich świat (Minczanowska, 2016, s. 220).

Ostatni rozdział do właściwie dyskusja wokół autorskich interpretacji przeanalizowanych wyników badań. Tadeusz Lewowicki w części „Stałość i zmienność wartości i aspiracji - trzeci szkic do charakterystyki uczniów z pogranicza polsko-czeskiego" (2016b) wysuwa pedagogicznie znaczącą konkluzję, że badania nad przekonaniami młodych ludzi na sprawy wartości, aspiracji, planów itp. są ważne dla namysłu nad kondycją człowieka i jego wspólnoty (Lewowicki, 2016b, s. 230). Pedagogiczna wiedza o tym, co wartościowe dla młodych, pozwala planować i realizować procesy edukacyjne im dedykowane. Jest to także impuls dla krytycznego i pedagogicznego namysłu nad kondycją młodych we współczesnym świecie. Najważniejszym chyba 
wnioskiem jest ten, który pokazuje, że młodzież dziś (tj. w latach 2014-2015) bardziej ceni wartości, które dotyczą życia jednostkowego niż wspólnotowego (Lewowicki, 2016b, s. 231, a także: Ogrodzka-Mazur, 2016b, s. 96, s. 97; Piechaczek-Ogierman, 2016, s. 171; Minczanowska, 2016, s. 214). To - jakby naturalnie - powoduje, że młodzi mniej cenią społeczne i wspólnotowe życie i mniej chętnie się w nie angażują, a także mniej chętnie biorą odpowiedzialność za innych (Lewowicki, 2016b, s. 231).

Podsumowując, trzeba pokreślić dwie kwestie. Po pierwsze, książka uzmysławia, że w pedagogicznych (i społecznych) badaniach takich antropologicznych spraw jak wartości i aspiracje nie można pomijać transformacji ustrojowej i tego, że wywiera ona wpływ nie tylko na doświadczenia pokoleń, które dorastały przed 1989 rokiem, ale decyduje ona też o losach osób, które urodziły się już po 1989 roku (Piechaczek-Ogierman, 2016, s. 171). Należy uznać, że transformacja społeczna, polityczna i ekonomiczna to punkt zwrotny w życiu każdej wspólnoty, że równocześnie przebudowuje ona życia jednostkowe, swoiście otwierając je na inny świat i wymuszając transformację ich systemów wartości, czego dowodzi Ewa Ogrodzka-Mazur (Ogrodzka-Mazur, 2016b, s. 35 i nn.). Najistotniejszą wartością, jaką przyniosła transformacja na pograniczu polsko-czeskim, jest otwarta granica między Republiką Czeską i Polską (Ogrodzka-Mazur, 2016a, s. 14 i nn., Ogrodzka-Mazur, 2016b, s. 24 i nn.).

Po drugie, książka prowokuje, aby czytać ją także poprzez deklarowane przez dzieci i młodzież wartości i aspiracje. Autorzy zostawiają w tekście liczne tropy, którymi czytelnik może podążać. Jednym z nich jest „pogranicze" i analizując wypowiedzi Autorów można w zasadzie przyjąć, że książka jest opowieścią o kondycji człowieka pogranicza (na co już zwracałam uwagę). Innym tropem jest wątek, w którym Ewa Ogrodzka-Mazur pisze o zaniku jednoznacznej identyfikacji polskiej i eksponowaniu samoidentyfikacji z regionem (śląskim lub morawskim). Byłaby to więc opowieść o zmaganiach „etniczności” (śląskości i morawskości) i „narodowości” (polskości i czeskości) z państwowością (i polską, i czeską), w obszarze różnicy kulturowej (Zaolzie). Jeszcze innym tropem jest ten, który niemal wprost wynika z opisów wspólnoty, które Autorzy konstruują w swych rozdziałach i do których odnoszą wyniki badań. Konstruują tym samym kolejno po sobie następujące opisy/szkice: wspólnoty demokracji liberalnej i wytwarzanego przez nią człowieka-obywatela (Ewa Ogrodzka-Mazur), wspólnoty kapitałowej i wytwarzanego przez nią człowieka-producenta (Gabierala Piechaczek-Ogierman) oraz wspólnoty konsumpcyjnej i wytwarzanego przez nią człowieka-konsumenta (Aleksandra Minczanowska). W tej perspektywie byłaby 
to więc opowieść o uwikłaniu „etniczności” i „narodowości” nie tylko w trzy różne typy wspólnot, ale nawet próba (czasowego) ustalenia, jak „etniczność" i „narodowość” są możliwe we wspólnotach, które organizują się na fundamentach trzech różnych antropologii i socjologii.

Tak czy inaczej, czytając książkę „Przemiany wartości i aspiracji życiowych", trzeba pamiętać, że dotyka ona kondycji człowieka konstruowanego nie tylko poprzez pogranicze, które w pewnym uproszczeniu można traktować jak pogranicze wielu (albo dwóch) kultur. Idzie tu także o kondycję człowieka, który konstruowany jest poprzez transformację ustrojową, i o człowieka, który na różne sposoby wikłany jest w różne wizje wspólnoty: i w tę liberalną (kulturę obywatelską), i w tę neoliberalną (kulturę kapitału i kulturę konsumpcjonizmu). Książka „Przemiany wartości...” jest dobrą egzemplifikacją tekstu, który skłania do krytycznego namysłu i dyskutowania z autorskimi interpretacjami wyników badań. To też przykład badań, który dzięki otwierającej formule jest cennym wkładem metodologicznym i teoretycznym w polską i europejską pedagogiką międzykulturową.

\section{Bibliografia}

Lewowicki, T. 2016a. Wstęp. W: Lewowicki, T. Ogrodzka-Mazur, E. Minczanowska, A. i Piechaczek-Ogierman, G. Sfery życia duchowego dzieci i młodzieży - studium z pogranicza polsko-czeskiego. Tom 1: Przemiany wartości i aspiracji życiowych. Toruń: Wydawnictwo Adam Marszałek, ss. 9-12.

Lewowicki, T. 2016b. Stałość i zmienność wartości i aspiracji - trzeci szkic do charakterystyki uczniów z pogranicza polsko-czeskiego. W: Lewowicki, T. Ogrodzka-Mazur, E. Minczanowska, A. i Piechaczek-Ogierman, G. Sfery życia duchowego dzieci i młodzieży - studium z pogranicza polsko-czeskiego. Tom 1: Przemiany wartości i aspiracji życiowych. Toruń: Wydawnictwo Adam Marszałek, ss. 230-237.

Lewowicki, T. Ogrodzka-Mazur, E. Minczanowska, A. i Piechaczek-Ogierman, G. 2016. Sfery życia duchowego dzieci i mtodzieży - studium z pogranicza polsko-czeskiego. Tom 1. Przemiany wartości i aspiracji życiowych. Toruń: Wydawnictwo Adam Marszałek.

Minczanowska, A. 2016. Samoocena, wzory osobowe i cenione przez uczniów z Pogranicza cechy u innych ludzi. W: Lewowicki, T. Ogrodzka-Mazur, E. Minczanowska, A. i Piechaczek-Ogierman, G. Sfery życia duchowego dzieci i młodzieży - studium z pogranicza polsko-czeskiego. 
Tom 1: Przemiany wartości i aspiracji życiowych. Toruń: Wydawnictwo Adam Marszałek, ss. 174-229.

Ogrodzka-Mazur, E. 2016a. Dzieci i młodzież z Pogranicza - uczniowie ze szkół podstawowych i gimnazjalnych w roku 2015 - charakterystyka środowiska i badanych grup. W: Lewowicki, T. Ogrodzka-Mazur, E. Minczanowska, A. i Piechaczek-Ogierman, G. Sfery życia duchowego dzieci i młodzieży - studium z pogranicza polsko-czeskiego. Tom 1: Przemiany wartości i aspiracji życiowych. Torun: Wydawnictwo Adam Marszałek, ss. 13-22.

Ogrodzka-Mazur, E. 2016b. Wartości cenione przez uczniów z pogranicza polsko-czeskiego. W: Lewowicki, T. Ogrodzka-Mazur, E. Minczanowska, A. i Piechaczek-Ogierman, G. Sfery życia duchowego dzieci i młodzieży studium z pogranicza polsko-czeskiego. Tom 1: Przemiany wartości i aspiracji życiowych. Toruń: Wydawnictwo Adam Marszałek, ss. 23-98.

Piechaczek-Ogierman, G. 2016. Aspiracje i plany życiowe dzieci i młodzieży. W: Lewowicki, T., Ogrodzka-Mazur, E. Minczanowska, A. i Piechaczek-Ogierman, G. Sfery życia duchowego dzieci i młodzieży - studium z pogranicza polsko-czeskiego. Tom 1: Przemiany wartości i aspiracji życiowych. Toruń: Wydawnictwo Adam Marszałek, ss. 99-173.

Adela Kożyczkowska 